Rapid Reviews COVID-19•

\title{
Reviews of "A Prenylated dsRNA Sensor Protects Against Severe COVID-19 and is Absent in Horseshoe Bats"
}

Margo Brinton' ${ }^{1}$, Alexei Korennykh², Roy Parker ${ }^{3}$, James Burke ${ }^{3}$ ${ }^{1}$ Georgia State University, Biology Dept., 623 PSC 161 Jesse Hill Jr Drive, Atlanta, Georgia, ${ }^{2}$ Princeton University, Molecular Biology, ${ }^{3}$ University of Colorado Biochemistry

Published on: Sep 16, 2021

License: Creative Commons Attribution 4.0 International License (CC-BY 4.0). 
To read the original manuscript, click the link above.

Summary of Reviews: This preprint colleagues perform a screen to identify interferon-stimulated genes that inhibit SARS-CoV-2 replication. The authors deem the study design as reliable and recommended only minor revisions.

Reviewer 1 (Margo Brinton) | प्र००

Reviewer 2 (Alexei Korennykh ) | 밈

Reviewer 3 (Roy Parker, James Burke) | प्र०ण

RR:C19 Strength of Evidence Scale Key.

$$
\begin{aligned}
& \text { प प्र०० = Misleading }
\end{aligned}
$$

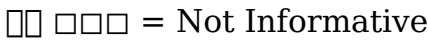

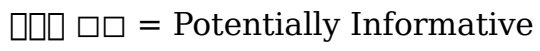

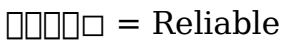

$$
\begin{aligned}
& \text { प्राप्र }=\text { Strong }
\end{aligned}
$$

To read the reviews, click the links below. 